\title{
СОСТОЯНИЕ ЛЕГАЛИЗАЦИИ ДОХОДОВ, ДОБЫТЫХ ПРЕСТУПНЫМ ПУТЕМ, С УЧЁТОМ ДЕЙСТВУЮЩЕГО УГОЛОВНОГО ЗАКОНОДАТЕЛЬСТВА
}

Аннотация: Исследовано состояние легализации доходов, добытых преступным путем, с учётом действующего уголовного законодательства. Обращено внимание, что в России ежегодно регистрируется несколько сотен тысяч преступлений экономической направленности, из них десятки тысяч преступлений связаны с получением преступного дохода в крупном или особо крупном размере (в 2010 г. - 51 969, в 2011 г. - 40 315, в 2012 2. - 36 083), что обусловливает их связь с «отмыванием». При этом соотношение легализации преступных доходов, предусмотренной статьями 174, 174.1 УК РФ, к указанным преступлениям составляет несколько процентов (в 2010 г. - 3\%, в 2011 2. - 1,7\%, в 2012 г. - 1,4\%). Латентность легализации преступных доходов связана с изменчивостью способов совершения этих преступлений, сложностью их доказывания, что затрудняет выявление и расследование таких криминальных деяний. По мнению автора, негативное влияние на эффективность использования правоохранительными органами апробированньх уголовно-правовых средств борьбы и превентивных мер по профилактике таких преступных посягательств оказывает нестабильность уголовного законодательства, связанная с частыми изменениями норм об уголовной ответственности за легализацию преступных доходов.В статье дан анализ практики и действующему законодательству России, позволяющему использовать легальные системы кредитно-финансовых отношений в противоправных целях. Таким образом, качество следствия по делам о легализации преступных доходов, обеспечиваемое посредством установления всех обстоятельств, подлежаших доказыванию, позволяет не только выявлять факторь, способствуюшие отмыванию преступных доходов, но и решать задачи разрушения экономической базы преступности, минимизации возможностей ее развития и воспроизводства. При этом меры профилактического характера реализуются как по отдельным уголовным делам, так и по результатам анализа группь дел, проводимого в целях более широкого сбора информации о преступлениях и организации деятельности правоохранительных органов по противодействию легализации доходов, полученных преступным путем. Эффективной мерой борьбе с данным видом преступной деятельности является также совериенствование системы информационного обеспечения по выявлению источников легализуюших преступные доходы. В определенной степени Росфинмониторинг является информационно-аналитическим органом, в который поступает основной объем информации о подозрительных операциях и сделках.

Abstract: The study concerns legalization of income attained by criminal means in accordance with the current criminal legislation. Attention is paid to the fact that several hundred thousand economic crimes are registered in Russia annually, and among these crimes tens of thousands of crimes are related to large and extra large criminal income (in 2010 - 51 969, in 2011 - 40 315, in 2012 - 36 083), which provides for their connection with “money laundering”. At the same time the correlation of these crimes and the crimes under the legalization of criminal income under Art. 174, 174.1 of the Criminal Code is just several per cent ( 3 per cent in 2010, 1,7 per cent in 2011, 1,4 per cent in 2012). Latent legalization of criminal income is related to the changing means of committing these crimes, complications with proving them, making revealing and investigation of such crimes difficult. In the opinion of the author the instability of criminal legislation and constant changes in the norms on criminal responsibility for the legalization of criminal income has a negative influence upon the use of proven preventive and interceptive measures against such crimes. The article contains analysis of practice and current legislation of Russia, allowing to use legal systems of credit and finances relations for the illegal purposes. Therefore, the investigation quality in the cases regarding legalization of criminal income, as guaranteed by revealing all circumstances, requiring proof, allows to uncover the factors facilitating money laundering and to solve the problems regarding destruction of the very economic basis for the crime, minimization of its development and reproduction. At the same time prophylactic measures are implemented both based on specific criminal cases, and upon the results of analysis of groups of cases, which is held in order to collect a wider range of information on crime and organization of activities of law-enforcement bodies in the sphere of fighting legalization of criminal profits. Improvement oft information guarantees also provides efficient means for fighting this type of criminal activities, since it allows for uncovering the sources for legalization of criminal income. To an extent, the Federal Financial Monitoring Service is an information and analytical body, which receives most of the information regarding suspicious deals and operations. 
Ключевые слова: легализация доходов, латентность, противодействие, факторы легализации, безопасность, ответственность, ущерб, преступление, транснациональный, экономика.

Keywords: legalization of income, latency, counteraction, legalization factors, security, responsibility, damage, crime, transnational, economics.

России в процессе проводимой по соображениям гуманности и либерализма декриминализации легализации (отмывания) денежных средств или иного имущества, приобретенных лицом в результате совершения им преступления (ст. 174.1 УК РФ), уголовная ответственность за нее стала возможной только с 6 млн. легализуемых средств. Это привело к тому, что за три последних года количество выявленных в России таких преступлений сократилось в 24 раза при обороте отмываемых криминальных капиталов в 2 трлн. руб. По существу произошло прекращение борьбы с легализацией преступных доходов, так как названные деяния продолжают совершаться, причем более интенсивно и на значительные суммы, но в размерах, не превышающих 6 млн. руб., либо большие суммы дробятся на мелкие, также не выходящие за пределы порога в 6 млн. руб., с которого наступает уголовная ответственность.

Анализ судебной практик показал , что легализация преступных доходов в абсолютном большинстве случаев выявлялась органами следствия как дополнительный состав к предикатному преступлению. Чаще всего, обвиняемым вменялось совершение преступлений, предусмотренных ст.ст. 174, 174.1 УК РФ в совокупности со ст.160 УК РФ - присвоение или растрата, ст. 159 УК РФ-мошенничество, ст.ст. 228-228.1 УК РФ-незаконный оборот наркотических средств, ст. 171 УК РФ-незаконное предпринимательство, ст. 260 УК РФ - незаконная рубка лесных насаждений. В период с 2009 по 2012 годы количество регистрируемых преступлений по ст. 174.1 УК РФ снизилось в 24 раза: с 8417 до 346, что во многом связано с декриминализацией данного преступления, отсекшей всю легализацию до 6 млн. руб., ограничив тем самым деятельность правоохранительных органов по ее выявлению.

Центральное место в системе нормативных правовых актов по вопросам противодействия легализации преступных доходов и финансирования терроризма занимает Федеральный закон № 115-Ф3 «О противодействии легализации (отмыванию) доходов, полученных преступным путем, и финансированию терроризма», определяя содержание связанных с ним положений иных федеральных законов, а так же принимаемых в его исполнение подзаконных актов ${ }^{1}$.

\footnotetext{
${ }^{1}$ Об утверждении Положения о представлении информации в Федеральную службу по финансовому мониторингу организациями, осуществляющими операции с денежными средствами или иным
}

В 2013 году был принят Федеральный закон № 134-Ф3 «О внесении изменений в отдельные законодательные акты Российской Федерации в части противодействия незаконным финансовым операциям», который соответствует международным обязательствам, которые взяла на себя Российская Федерация, ратифицировав большую часть международных конвенций в данной области.

Легализация «отмывание» доходов, полученных преступным путем, определяется как придание правомерного вида владению, пользованию или распоряжению денежными средствами или иным имуществом, полученными в результате совершения преступления ${ }^{2}$. Понятие «легализация» определяется путем фиксирования способа совершения деяния и его цели. Учёные отмечают, что «отмыванию» денег присущ неотъемлемый элемент - цель, которая состоит в сокрытии источника происхождения дохода, создании иллюзии (видимости) легальности заведомо нелегального дохода, и возможности в дальнейшем использовать денежные средства или иное имущество, приобретенное преступным путем, для осуществления экономической деятельности различного рода ${ }^{3}$.

имуществом, и индивидуальными предпринимателями и направлении Федеральной службой по финансовому мониторингу запросов в организации, осуществляющие операции с денежными средствами или иным имуществом, и индивидуальным предпринимателям: постановление Правительства РФ от 19.03.2014 № 209; Типовые вопросы применения отдельных норм Федерального закона от 07.08.2001 № 115-Ф3 «О противодействии легализации (отмыванию) доходов, полученных преступным путем, и финансированию терроризма»: информационное сообщение Федеральной службы по финансовому мониторингу от 16 января 2014 г. Электронный pecypc. Информационно-правовой портал «Гарант». URL: http:// www.garant.ru/. Дата обращения (24.03.2014).

2 O противодействии легализации (отмыванию) доходов, полученных преступным путем, и финансированию терроризма: фед. закон от 07.08.2001 № 115-ФЗ с изм. и доп. ; в ред. от 28.12.2013 № 403-ФЗ. Электронный ресурс. Информационно-правовой портал «Гарант». URL: http://www.garant.ru/. Дата обращения (24.03.2014).

${ }^{3}$ См.: Ларичев В.Д. Совершенствование законодательства о борьбе с «отмыванием» денег, полученных преступным путем // Государство и право. 2003. № 2. С. 100; Алиев В.М. Легализация (отмывание) доходов, полученных незаконным путем. Уголовноправовое и криминологическое исследование: Монография. М.: Институт современного права, 2001. С. 16; Кочарян А.M Уголовно-правовая и криминологическая мера противодействия легализации (отмыванию) денежных средств или иного имущества, приобретенных преступным путем: Автореф. дис. ... канд, юрид. наук. М., 2003. C. 8-9. 
DOI: 10.7256/1811-9018.2014.6.12061

При цитировании этой статьи сноска на dоі обязательна

\section{Право и политика $6(174) \cdot 2014$}

Так, доходы, полученные преступным путем, могут использоваться на следующие цели:

1) покрытие текущих расходов преступников и их окружения (на организацию преступлений и на потребление);

2) накопление (в виде наличных денежных средств, драгоценностей, иных предметов роскоши и т.п.);

3) развитие преступной деятельности (расширение основного вида деятельности и ее диверсификация);

4) инвестиции в легальную экономику (размещение на финансовом рынке, приобретение недвижимости и т.п.).

Достижение этих целей преступниками неизбежно влечет за собой все большее развитие организованной преступности, что позволяет им расширять свою преступную деятельность, устанавливать контроль над легальным сектором экономики, то есть происходит создание замкнутой преступной системы и превращение её в высокодоходное и эффективное производство 4 .

Учеными выделяются основные признаки легализации преступных доходов:

- совершение предшествуюшего преступления, в результате которого преступниками приобретаются материальные блага, которыми чаще всего сразу распорядиться они не могут;

- совершение действий с преступными доходами, цель таковых действий - придание правомерного вида владению, пользованию или распоряжению такими доходами;

- сокрытие следов происхождения преступных доходов;

- сокрытие лиц, извлекающих незаконные доходы и инициирующие сам процесс отмывания;

- создание видимости законности получения доходов;

- уклонение от уплаты налогов;

- создание удобного и оперативного доступа к денежным средствам, полученным из нелегальных источников;

- обеспечение условий для безопасного инвестирования в легальный бизнес 5 .

В соответствии и на основании этих признаков в качестве альтернативного определения легализацией (отмыванием) доходов, полученных преступным путем, можно считать умышленное искажение сведений об истинном источнике и владельце прав на преступно приобретенные

\footnotetext{
${ }^{4}$ Корчагин О.Н., Колесников К.А. Организация противодействия легализации (отмыванию) доходов, полученных преступным путем, в том числе от незаконного оборота наркотиков / Под ред. И.И. Батыршина; учебное пособие. М., 2013. С. 19.

${ }_{5}^{5}$ Корчагин О.Н. Административно-правовые основы противодействия легализации (отмыванию) доходов, полученных преступным путем, в Российской Федерации: Автореферат дис. канд. юрид. наук., М., 2010. С. 8-9.
}

материальные блага, осуществляемое путем введения таковых благ в легальный экономический оборот, с целью сокрытия факта их незаконного приобретения и обеспечения возможности свободно ими распоряжаться. Данное определение указывает на предмет преступления, его метод и цель, раскрывает его антиобщественную направленность и противоправную сущность ${ }^{6}$.

Н. А. Башьян выделяет организованную легализацию доходов от мошенничества как вид криминального обмана в сфере экономики, включающий целостную совокупность совершенных в составе организованной группы, в том числе преступного сообщества (преступной организации), финансовых операций и других сделок с денежными средствами, иным имуществом и правами на него, заведомо приобретенными виновным или другими лицами путем совершения мошенничества, в целях придания правомерного вида владению, пользованию и распоряжению соответствующими денежными средствами, иным имуществом и правами на него, а также лиц, совершивших такие преступления ${ }^{7}$.

По мнению Р.В. Жубрина под легализацией преступных доходов следует понимать совершение маскируемых под законные сделок и финансовых операций с преступными доходами с целью сокрытия их преступного происхождения и придания правомерности владению, пользованию и распоряжению ими. Такая дефиниция дает возможность отличать эти преступления от иных форм оборота преступно полученных денежных средств или иного имущества (приобретение или сбыт имущества, заведомо добытого преступным путем, финансирование преступной деятельности, потребление преступных доходов), а также повысить уровень профилактического противодействия легализации преступных доходов ${ }^{8}$.

Легализация денежных средств или иного имущества, полученных в результате совершения преступления, - это социальный феномен, имеющий определенные причины возникновения и дальнейшего развития, характеризующийся высокой степенью общественной опасности, а именно: транснационализация капиталов, появление денежных средств, заработанных на разнице в налоговом законодательстве нескольких стран, проникновением преступно нажитых капиталов в легальную экономику. Легализация денежных средств или иного имущества, полученных в результате совершения

\footnotetext{
${ }^{6}$ Корчагин О.Н., Колесников К.А. Указ. соч. С. 19-20.

${ }^{7}$ Башьян Н. А. Противодействие организованной легализации доходов от мошенничества: Криминологический и уголовно-правовой аспекты : автореферат дис. ... канд. юрид. наук. М., 2008. С. 10.

8 Жубрин Р.В. Основы профилактики легализации преступных доходов: автореферат дис. ... доктора юрид. наук, М., 2013. С. 11.
} 
транснациональных операций, либо обналичивания через подставные фирмы, является составной частью деятельности организованной преступности, способствует росту коррупциия.

Выделяют основные факторы, влияющие на развитие легализации (отмывания) преступных доходов: правовые, политические и экономические.

К правовым факторам относят отсутствие во многих странах удовлетворительного правового регулирования в этой сфере, что достаточно долго не позволяло сформироваться устойчивой судебной практике. Достаточно вспомнить о том, что и Российская Федерация в свое время попадала в «черный» список ФАТФ - стран, не сотрудничающих в борьбе с отмыванием «грязных» денег, и была исключена из него во многом благодаря принятию Федерального закона № 115-ФЗ. Кроме того, известно, что, несмотря на ратификацию в 1990 году Венской конвенции от 20.12.1988г., до 1996 года ни одна из ее рекомендаций по криминализации «отмывания» средств, получаемых от сбыта наркотических средств и психотропных веществ, не была исполнена.

Среди экономических факторов, способствующих легализации денежных средств или иного имущества, полученных преступным путем выделяется нестабильность российской экономики, хотя в последнее время такой стабильностью не может похвалиться ни одно из развитых демократических государств, что только усугубляет проблему, ввиду того, что легализация (отмывание) преступных доходов носит, как правило, транснациональный характер. В настоящее время Россия предпринимает серьезные шаги к повышению качества государственного регулирования экономики. Однако чрезмерная открытость российской экономики может привести к значительному оттоку денежных средств или иному отчуждению имущества, добытых преступным путем и, соответственно, создает возможность легализации их за рубежом.

К политическим факторам следует отнести высокий уровень коррупционности в исполнительных, правоохранительных и судебных органах Российской Федерации, а так же в банковской системе, присутствие в законодательных органах лиц напрямую заинтересованных в понижении качества государственного противодействия стоящей проблеме. В результате этого создается возможность лоббирования принятия органами государственной власти законодательных и подзаконных нормативных

\footnotetext{
${ }^{9}$ Кириленко В.С. Уголовно-правовая и криминологическая характеристика легализации (отмывания) денежных средств или иного имущества, приобретенных преступным путем: автореферат дис. ... канд. юрид. наук, Ростов-на-Дону, 2012. С.6.
}

правовых актов в интересах организованных преступных групп, занимающихся «отмыванием» денег.

На наш взгляд, следует согласиться с И.А. Киселевым, считающим, что, одним из главных факторов, способствующих развитию отмывания преступных доходов в России является отсутствие на протяжении долгого времени политической воли к противодействию негативным явлениям в обществе и низкий уровень правосознания значительной части населения, следствие чего - дезориентация и наркотизация молодежи, рост уровня устойчивости, организованности и активности преступности и колоссальные масштабы криминальных накоплений ${ }^{10}$.

Таким образом, общими факторами, способствующими легализации преступных доходов, являются: 1) дисбаланс между финансовой системой и производственной базой, что способствует росту спекулятивного капитала; 2) неограниченная свобода финансовых операций нерезидентов России; 3) недостатки системы производства и распределения общественных благ, влекущие социальные противоречия; 4) значительный уровень преступлений, создающих преступные доходы; 5) недостаточное обеспечение социальных прав в сложных экономических условиях; 6) высокая стратификация общества; 7) недостатки механизмов социального контроля ${ }^{11}$.

Среди главных итогов 2013 года в национальной системе противодействия отмыванию доходов и финансированию терроризма - успешная защита Отчета о прогрессе Российской Федерации перед экспертами ФАТФ и принятие Федерального закона №134-Ф3. Это стало возможным во многом благодаря согласованным действиям всех заинтересованных участников, в том числе, в рамках Межведомственной рабочей группой по противодействию незаконным финансовым операциям (МРГ), созданной распоряжением Президента Российской Федерации 31 июля 2012 года, информационно-аналитическое сопровождение которой осуществляет Росфинмониторинг.

12 января 2012 года В.В. Путин поручил Виктору Зубкову в целях повышения результативности работы по выявлению и пресечению финансовых операций (в том числе с использованием «фирм-однодневок»), направленных на легализацию доходов, полученных преступным путём, финансирование терроризма, уклонение от уплаты налогов и таможенных платежей,

\footnotetext{
${ }^{10}$ См.: Киселев И.А. Грязные деньги: Уголовная ответственность за отмывание преступных доходов и ее применение в борьбе с преступностью и коррупцией. М.: ИД «Юриспруденция», 2009.

${ }^{11}$ Жубрин Р.В. Основы профилактики легализации преступных доходов: автореферат дис. ... доктора юрид. наук, М., 2013. С. 12.
} 
DOI: $10.7256 / 1811-9018.2014 .6 .12061$

При цитировании этой статьи сноска на dоі обязательна

\section{Право и политика 6 (174) • 2014}

получения коррупционных доходов, сформировать межведомственную рабочую группу под его руководством с участием представителей правоохранительных органов, Банка России и ФНС России, а также обеспечить работу группы на регулярной основе ${ }^{12}$.

4 марта 2014 года, Владимир Путин подписал Перечень поручений по итогам совещания с членами Правительства Российской Федерации, состоявшегося 12 февраля 2014 года:

1. Правительству Российской Федерации совместно с Центральным банком Российской Федерации:

a) обеспечить внесение в законодательство Российской Федерации изменений, направленных:

на установление в отношении должностных лиц финансовых организаций уголовной ответственности за фальсификацию отчётности независимо от наличия ущерба, причинённого в результате такой фальсификации;

на определение механизмов противодействия распространению заведомо ложных сведений о финансовом состоянии кредитных и иных публичных финансовых организаций из анонимных источников;

на совершенствование механизмов обязательного страхования гражданской ответственности владельцев транспортных средств (повышение эффективности защиты прав потерпевших на возмещение вреда, причинённого их жизни, здоровью или имуществу при использовании транспортных средств иными лицами);

на совершенствование процедур финансового оздоровления и ликвидации кредитных организаций, в том числе изменение очерёдности удовлетворения требований вкладчиков банка (граждан и индивидуальных предпринимателей), вклады которых не превышают 1 млн. рублей;

на повышение эффективности механизма формирования фонда страхования вкладов в части, касающейся дифференциации ставок взносов в данный фонд;

на обеспечение возможности оплаты гражданами в безналичной форме товаров, работ и услуг, поставляемых (выполняемых, оказываемых) организациями и индивидуальными предпринимателями, ежегодный денежный оборот которых без учёта налога на добавленную стоимость превышает 60 млн. рублей, с одно- временным введением мер, направленных на снижение издержек граждан, организаций и индивидуальных предпринимателей при совершении таких операций. Срок - 1 июня 2014 г.;

б) рассмотреть вопросы:

совершенствования механизмов воздействия на кредитные организации в целях предупреждения проведения ими сомнительных операций;

создания системы унифицированных требований, направленных на противодействие легализации (отмыванию) доходов, полученных преступнымпутём, и финансированию терроризма, для некредитных финансовых организаций;

внедрения в систему страхования электронного страхового полиса;

совершенствования механизмов противодействия неправомерному использованию инсайдерской информации и манипулированию рынком;

определения механизмов регулирования внебиржевого рынка Форекс;

совершенствования механизмов осуществления пенсионной реформы в части, касающейся уточнения правовых режимов деятельности негосударственных пенсионных фондов ${ }^{13}$.

Важным показателем эффективного функционирования системы противодействия отмывания денег и финансирования терроризма является количество вовлечённых в неё организаций, а также качество и количество предоставленных ими сообщений. За 2011 год межрегиональными управлениями Росфинмониторинга на учёт было поставлено около 2,8 тысяч организаций, из которых около 70\% составили ломбарды и риэлторы (см. рис. 1).

\begin{tabular}{|l|}
\hline $\begin{array}{l}\square \text { факторинговые } \\
\text { организации }\end{array}$ \\
$\begin{array}{l}\text { лизинговые } \\
\text { компании }\end{array}$ \\
$\square$ ломбарды \\
$\square$ операторы по \\
приему \\
платежей
\end{tabular}

Рис. 1. Организаџии, поставленнье на учёт в Росфинмониторинге в 2011 году

\footnotetext{
12 Поручение о создании рабочей группы по пресечению незаконных финансовых операций // Официальный сайт «Президент России/События». [эл. pecypc]: http://kremlin.ru/ assignments/14263\#sel=1:1,1:69. Дата обращения 21.04.2014.
}

\footnotetext{
${ }^{13}$ Перечень поручений по итогам совещания с членами Правительства России от 4 марта 2014 года. // Официальный сайт «Президент России/События». [эл. pecypc]: http://kremlin.ru/assignments/20392. Дата обращения 22.04.2014
} 
Количество организаций, состоящих на учете в финансовой разведке, за 2013 год выросло примерно на $2 \%{ }^{14}$, превысив 24 тысячи. Почти на $50 \%$ вырос объем информации от посредников в сделках с недвижимостью, что обусловлено как изменением общего количества субъектов (в том числе за счет появления новых - индивидуальных предпринимателей), так и повышением качеством работы служб внутреннего контроля и надзора со стороны Росфинмониторинга (см. рис.2).

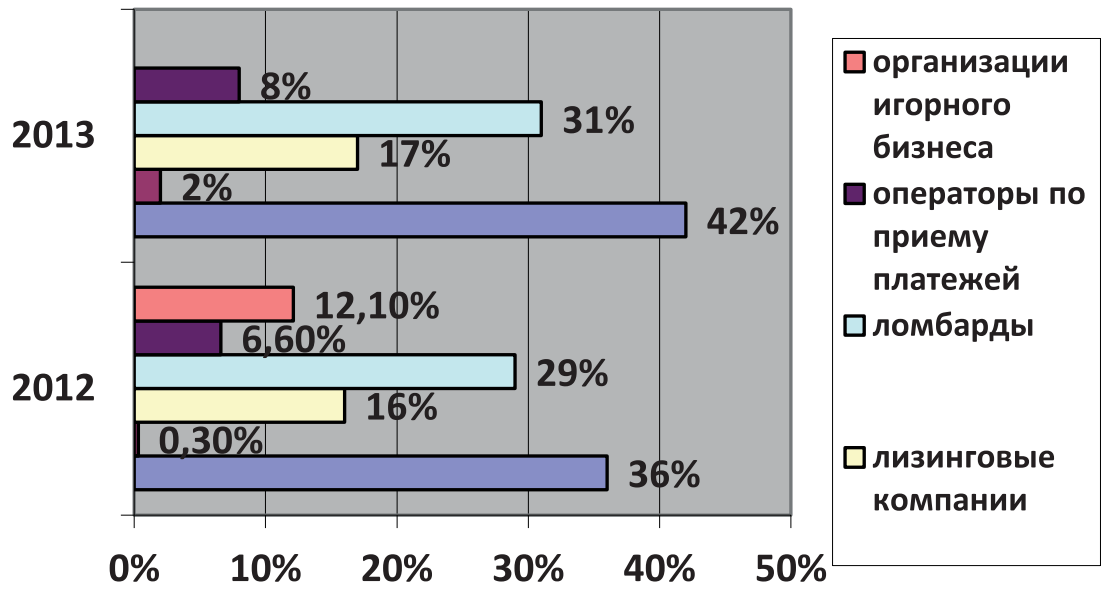

Рис. 2. Организации, поставленные на учёт в Росфинмониторинге в 2012 и 2013 годаx

Общее количество финансовых расследований, проведенных по противодействию легализации (отмывании) преступных доходов в 2012 году, выросло на 40\% по сравнению с 2011 годом. За 2012 год поступило около 3000 сообщений об операциях отмывания денег, это более чем в 2 раза по сравнению с предыдущим годом.

В 2013 году общее количество финансовых расследований по линии противодействия отмыванию доходов сохранило тенденцию роста: по отношению к 2012 году - на $11 \%$.

Характерной особенностью технологии отмывания криминальных денег в России является незаконное обналичивание

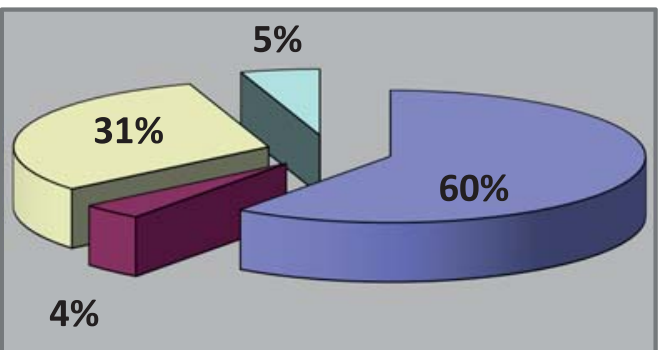
деятельности организаций, является особенностью системы государственного контроля, который своей эффективной деятельностью может сократить финансирование терроризма. В 2012 году Росфинмониторинга было проведено ряд проверок по запросам и обращениям (см рис. 3).

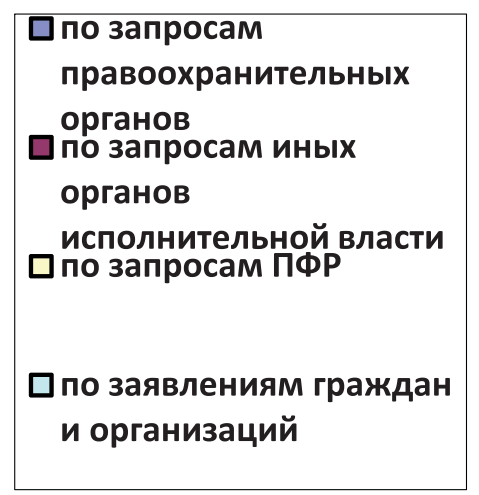

Рис.3. Проверки по запросам и обращееним в 2012 году денежных средств с целью сокрытия следов происхождения и последующего вовлечения в нелегальный либо гальный хозяйственный оборот.

ского центра МВД, в январе-ноябре 2011 г. на территории России выявлено свыше 56,7 тыс. преступлений экономической направленности, следствие по которым обязательно, совершенных в финансово-кредитной органами внутренних дел, что составляет $99,1 \%$. В том числе правоохранительными органами выявлено 457 преступлений, предусмотренных ст. 193 УК РФ (невозвращение из-за границы средств в иностранной валюте), что на $28 \%$ больше, чем за 11 месяцев предыдущего года. Более половины преступлений выявлены сотрудниками органов внутренних дел ${ }^{15}$.

Распределение контрольно-надзорных полномочий между различными органами, осуществляющими надзор в основной сфере 
DOI: $10.7256 / 1811-9018.2014 .6 .12061$

При цитировании этой статьи сноска на dоі обязательна

\section{Право и политика $6(174) \cdot 2014$}

От поднадзорных Росфинмониторингу организаций в 2013 году поступило около 400 тысяч сообщений, при этом основным поставщиком информации традиционно являлись лизинговые компании - на их долю приходится $45 \%$ информации.

В целом, объем сведений в 2013 году по сравнению с 2012 увеличился - на 35\%. Структура данных изменилась - на долю сообщений о подозрительных операциях приходится порядка 16\% (2012 - 7,5\%), количество таких сведений возросло почти в 3 раза.

Также более, чем в 3 раза выросло количество сообщений, направляемых ломбардами, объем информации о сомнительных операциях - увеличился в 5 раз.

Почти на 50\% вырос объем информации от посредников в сделках с недвижимостью, что обусловлено как изменением общего количества субъектов (в том числе, за счет появления новых - индивидуальных предпринимателей), так и повышением качества работы служб внутреннего контроля и надзора со стороны Росфинмониторинга (см. рис. 4).

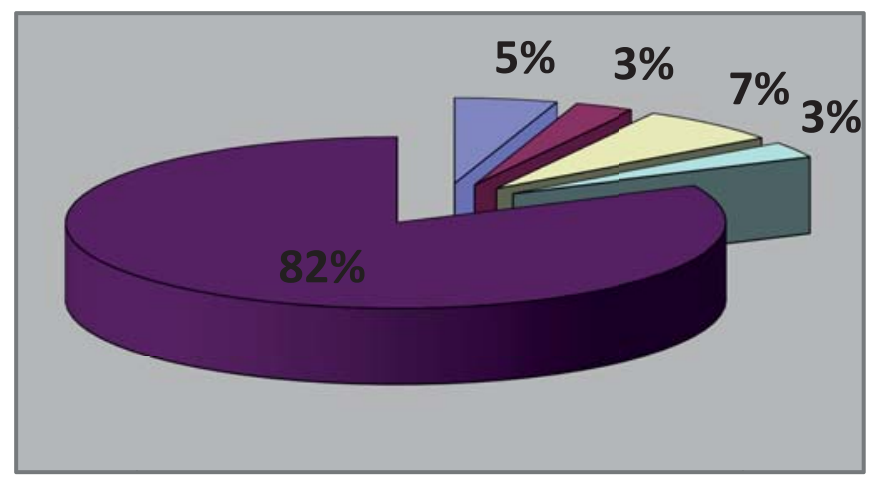

Рис.4. Проверки по запросам и обращениям в 2012 году

Большая часть преступлений, квалифицируемых по ст. ст. 174 и 174-1 УК РФ, выявлена в 2011 году в кредитно-финансовой системе - около 300. В 2012 году довольно значительно выросли показатели использования переданных Росфинмониторингом материалов при расследовании уголовных дел: таких случаев 437 - по предикатным статьям, и в 112 - по ст.ст. 174 и 174-1 УК.

В 2013 году общее количество финансовых расследований по линии противодействия отмыванию доходов сохранило тенденцию роста: по отношению к 2012 году - на $11 \%$. В суды по сравнению с предыдущим годом передано сопоставимое количество уголовных дел, при расследовании которых использовались материалы Росфинмониторинга. Из них на 41\% больше, чем в 2012 году, квалифицировано по статьям 174 и 174.1 УК РФ.
По оценке Банка России, в 2012 году теневой оборот финансового рынка составил порядка 12-14 триллионов рублей. Примером могут служить ростовские и московские банкиры, которые попали в скамью подсудимых.

По данным УФСБ и ДЭБ МВД России их теневой оборот составил 90 млрд. руб.

В течение 2012 года совместно с Банком России продолжена работы в отношении «теневых банковских площадок». Проанализировано свыше ста банков, из них по 73 материалы направлены в правоохранительные органы.

Главной целью деятельности подразделений экономической безопасности органов внутренних дел является: предупреждение, выявление и пресечение преступлений, связанных с незаконной банковской деятельностью, в том числе незаконным обналичиванием денежных средств, а также противоправным выводом капиталов за границу.

По данным, опубликованным Департаментом экономической безопасности МВД РФ, деятельность пре-

\begin{tabular}{|c|}
\hline 口по запросам иных ФОИВ \\
\hline $\begin{array}{l}\text { 口по заявлениям граждан } \\
\text { и организаций }\end{array}$ \\
\hline $\begin{array}{l}\text { 口в инициативном } \\
\text { порядке }\end{array}$ \\
\hline $\begin{array}{l}\text { 口по запросам } \\
\text { зарубежных ПФР }\end{array}$ \\
\hline 口по запросам По \\
\hline
\end{tabular}

ступников, связанная с легализацией незаконных доходов, в 2012 году нанесла ущерб на сумму 14,2 млрд. рублей. По данным Главного информационно-аналитического центра МВД России, по итогам года зафиксировано 22 преступления, связанных с оказанием содействия терроризму, в том числе с финансированием террористической и экстремистской деятельности. В частности, была нейтрализована организованная преступная группа, которая осуществляла незаконные банковские операции по обналичиванию денег, поступавших из Дагестана. Эти средства конвертировались в иностранную валюту, а затем выводились за границу через «фирмы-однодневки». Ущерб государству составил более 850 млн. рублей ${ }^{16}$.

Согласно официальной статистике МВД России по сравнению с январем - декабрем 2012 года на 18,4\%

\footnotetext{
${ }^{16}$ Асланян Л.С. Противодействие легализации доходов, полученных преступным путем, и финансировании терроризма. Ростов-наДону, 2014. С. 15-17. [эл. pecypc]: http://www.scienceforum.ru/2014/ pdf/6685.pdf. Дата обращения 12.04.2014.
} 
сократилось число преступлений экономической направленности, выявленных правоохранительными органами. Всего выявлено 141,2 тыс. преступлений данной категории, удельный вес этих преступлений в общем числе зарегистрированных составил 6,4\%.

Материальный ущерб от указанных преступлений (по оконченным уголовным делам) составил 229,86 млрд руб.

Тяжкие и особо тяжкие преступления в общем числе выявленных преступлений экономической направленности составили 57,8\%. Подразделениями органов внутренних дел выявлено 130 тыс. преступлений экономической направленности, их удельный вес в общем массиве преступлений экономической направленности составил $92,0 \%{ }^{17}$.

Таким образом, качество следствия по делам о легализации преступных доходов, обеспечиваемое посредством установления всех обстоятельств, подлежащих доказыванию, позволяет не только выявлять факторы, способствующие отмыванию преступных доходов, но и решать задачи разрушения экономической базы преступности, минимизации возможностей ее развития и воспроизводства. При этом меры профилактического характера реализуются как по отдельным уголовным делам, так и по результатам анализа группы дел, проводимого в целях более широкого сбора информации о преступлениях и организации деятельности правоохранительных органов по противодействию легализации доходов, полученных преступным путем.

Эффективной мерой борьбе с данным видом преступной деятельности является также совершенствование системы информационного обеспечения по выявлению источников легализующих преступные доходы. В определенной степени Росфинмониторинг является информационно-аналитическим органом, в который поступает основной объем информации о подозрительных операциях и сделках.

\section{Библиография:}

1. Ларичев В.Д. Совершенствование законодательства о борьбе с «отмыванием» денег, полученных преступным путем // Государство и право. 2003. № 2. С. 100.

2. Алиев В.М. Легализация (отмывание) доходов, полученных незаконным путем. Уголовно-правовое

\footnotetext{
${ }^{17}$ Краткая характеристика состояния преступности в Российской Федерации за январь - декабрь 2013 года. [эл. ресурс]: http://mvd. ru/Deljatelnost/statistics/reports/item/1609734/. Дата обращения 12.04.2014.
}

и криминологическое исследование: Монография. М.: Институт современного права, 2001. С. 16

3. Кочарян А.М Уголовно-правовая и криминологическая мера противодействия легализации (отмыванию) денежных средств или иного имущества, приобретенных преступным путем: Автореф. дис. ... канд, юрид. наук. М., 2003. С. 8-9.

4. Корчагин О.Н., Колесников К.А. Организация противодействия легализации (отмыванию) доходов, полученных преступным путем, в том числе от незаконного оборота наркотиков / Под ред. И.И. Батыршина; учебное пособие. М., 2013. С. 19.

5. Корчагин О.Н. Административно-правовые основы противодействия легализации (отмыванию) доходов, полученных преступным путем, в Российской Федерации: Автореферат дис. канд. юрид. наук., М., 2010. C. 8-9.

6. Башьян Н. А. Противодействие организованной легализации доходов от мошенничества: Криминологический и уголовно-правовой аспекты: автореферат дис. ... канд. юрид. наук. М., 2008. C. 10 .

7. Жубрин Р.В. Основы профилактики легализации преступных доходов: автореферат дис. ... доктора юрид. наук, М., 2013. С. 11.

8. Кириленко В.С. Уголовно-правовая и криминологическая характеристика легализации (отмывания) денежных средств или иного имущества, приобретенных преступным путем: автореферат дис. ... канд. юрид. наук, Ростов-на-Дону, 2012. С.6.

9. Киселев И.А. Грязные деньги: Уголовная ответственность за отмывание преступных доходов и ее применение в борьбе с преступностью и коррупцией. М.: ИД «Юриспруденция», 2009.

10. Асланян Л.С. Противодействие легализации доходов, полученных преступным путем, и финансировании терроризма. Ростов-на-Дону, 2014. С. 15-17. [эл. pecypc]: http://www.scienceforum. ru/2014/pdf/6685.pdf. Дата обращения 12.04.2014.

11. Паненков А.А. Проблемы совершенствования национальной системы противодействия легализации доходов, полученных преступным путем, и финансированию терроризма и оружия массового уничтожения // NB: Экономика, тренды и управление. - 2014. - 1. - С. 13-30. DOI: 10.7256/23064595.2014.1.8110. URL: http://www.e-notabene.ru/etc/ article_8110.html

12. Леньшин Д.И. Уголовные наказания за преступления экстремистской направленности: проблемы 
DOI: $10.7256 / 1811-9018.2014 .6 .12061$

При цитировании этой статьи сноска на dоі обязательна

\section{Право и политика $6(174) \cdot 2014$}

законодательного закрепления и реализации // Административное и муниципальное право. - 2011. - 4. - С. 38-42.

13. Паненков А.А. Проблемы совершенствования национальной системы противодействия легализации доходов, полученных преступным путем, и финансированию терроризма и оружия массового уничтожения // NB: Экономика, тренды и управление. - 2014. - № 1. - C.13-30. DOI: 10.7256/23064595.2014.1.8110. URL: http://e-notabene.ru/etc/ article 8110.html

14. Лопатина В.В.. Проблемы наркотрафика и легализация наркотиков в Латинской Америке // Международные отношения. - 2014. - № 1. - С. 104 107. DOI: $10.7256 / 2305-560 X .2014 .1 .10242$

15. Иванов А.Г.. Легализация драгоценных металлов, полученных преступным путем: проблемы привлечения к уголовной ответственности // Право и политика. - 2013. - № 2. - C. 104-107. DOI: 10.7256/1811-9018.2013.02.18

16. Паненков А.А. Криминологические подходы к решению проблем борьбы с терроризмом и его финансированием и особенности прокурорского надзора. Некоторые предложения по оптимизации борьбы с терроризмом и его финансированием на основе научных исследований // NB: Национальная безопасность. - 2013. - № 3. - C.17-135. DOI: 10.7256/2306-0417.2013.3.8754. URL: http://enotabene.ru/nb/article_8754.html

17. Паненков А.А. Криминологическая обусловленность государственной политики по борьбе с преступностью является залогом успеха обеспечения федеральной безопасности России, а также борьбы с терроризмом и его финансированием // NB: Национальная безопасность. - 2012. - № 2. C.188-236. DOI: 10.7256/2306-0417.2012.2.90. URL: http://e-notabene.ru/nb/article_90.html

18. Мурадян С.В. Институциональные основы борьбы с финансированием терроризма в Европейском союзе // NB: Российское полицейское право. - 2013. - № 2. - C.77-90. DOI: 10.7256/2306-4218.2013.2.800. URL: http:/e-notabene.ru/pm/article_800.html

19. Паненков А.А. Предварительный анализ реагирования правоохранительных органов и спецслужб на преступления террористической направленности в 2012 году и прогноз на 2013 год в России. Результаты научных исследований 2010-2012 гг. по борьбе с источниками финансирования терроризма в Республике Ингушетия (выводы и предложения) // NB: Национальная безопасность. - 2013. - № 1. -
C.153-253. DOI: 10.7256/2306-0417.2013.1.326. URL: http://e-notabene.ru/nb/article_326.html

20. Паненков А.А. Криминологическая обусловленность государственной политики по борьбе с преступностью-залог успеха в борьбе с терроризмом и его финансированием в России // NB: Национальная безопасность. - 2012. - № 1. - C.1-54. DOI: 10.7256/2306-0417.2012.1.109. URL: http://enotabene.ru/nb/article_109.html

21. Паненков А.А. Борьба с терроризмом и его финансированием останется актуальной и долговременной проблемой для России // NB: Национальная безопасность. - 2013. - № 4. - C.19-77. DOI: 10.7256/2306-0417.2013.4.187. URL: http://e-notabene. $\mathrm{ru} / \mathrm{nb} /$ article_187.html

22. Малышенко Н.Г.. Бизнес-мониторинг - современный инструмент экономической безопасности федерального автономного вуза // Национальная безопасность / nota bene. - 2013. - № 5. - С. 104-107. DOI: $10.7256 / 2073-8560.2013 .5 .9556$

23. А.А. Паненков. Направления совершенствования борьбы с терроризмом и его финансированием (по результатам проведенных исследований) // Финансовое право и управление. - 2013. - № 1. С. 104-107. DOI: 10.7256/.2013.1.4806

24. Астанин В.В. Противодействие коррупции: перспективные подходы к предупреждению и возмещению ущерба // Административное и муниципальное право. - 2013. - 7. - C. 719 - 722. DOI: 10.7256/1999-2807.2013.7.9084.

25. Антонова Е.Ю. Уголовная ответственность корпоративного (коллективного) субъекта за коррупционные преступления // NB: Вопросы права и политики. - 2013. - 3. - C. 192 - 220. DOI: 10.7256/2305-9699.2013.3.568. URL: http://www.enotabene.ru/lr/article_568.html

26. Акопджанова М.О. Формирование современного законодательства Российской Федерации об уголовной ответственности за преступления против установленного порядка уплаты налогов и сборов // Право и политика. - 2013. - 8. - С. 1022 - 1026. DOI: $10.7256 / 1811-9018.2013 .8 .8390$.

\section{References (transliteration):}

1. Larichev V.D. Sovershenstvovanie zakonodatel'stva o bor'be s «otmyvaniem» deneg, poluchennykh prestupnym putem // Gosudarstvo i pravo. 2003. № 2. S. 100 . 
2. Aliev V.M. Legalizatsiya (otmyvanie) dokhodov, poluchennykh nezakonnym putem. Ugolovno-pravovoe i kriminologicheskoe issledovanie: Monografiya. M.: Institut sovremennogo prava, 2001. S. 16

3. Kocharyan A.M Ugolovno-pravovaya i kriminologicheskaya mera protivodeistviya legalizatsii (otmyvaniyu) denezhnykh sredstv ili inogo imushchestva, priobretennykh prestupnym putem: Avtoref. dis. ... kand, yurid. nauk. M., 2003. S. 8-9.

4. Korchagin O.N., Kolesnikov K.A. Organizatsiya protivodeistviya legalizatsii (otmyvaniyu) dokhodov, poluchennykh prestupnym putem, $\mathrm{v}$ tom chisle ot nezakonnogo oborota narkotikov / Pod red. I.I. Batyrshina; uchebnoe posobie. M., 2013. S. 19.

5. Korchagin O.N. Administrativno-pravovye osnovy protivodeistviya legalizatsii (otmyvaniyu) dokhodov, poluchennykh prestupnym putem, v Rossiiskoi Federatsii: Avtoreferat dis. kand. yurid. nauk., M., 2010. S. 8-9.

6. Bash'yan N. A. Protivodeistvie organizovannoi legalizatsii dokhodov ot moshennichestva: Kriminologicheskii i ugolovno-pravovoi aspekty : avtoreferat dis. ... kand. yurid. nauk. M., 2008. S. 10.

7. Zhubrin R.V. Osnovy profilaktiki legalizatsii prestupnykh dokhodov: avtoreferat dis. ... doktora yurid. nauk, M., 2013. S. 11.

8. Kirilenko V.S. Ugolovno-pravovaya i kriminologicheskaya kharakteristika legalizatsii (otmyvaniya) denezhnykh sredstv ili inogo imushchestva, priobretennykh prestupnym putem: avtoreferat dis. ... kand. yurid. nauk, Rostov-na-Donu, 2012. S.6.

9. Kiselev I.A. Gryaznye den'gi: Ugolovnaya otvetstvennost' za otmyvanie prestupnykh dokhodov i ee primenenie v bor'be s prestupnost'yu i korruptsiei. M.: ID «Yurisprudentsiya», 2009.

10. Aslanyan L.S. Protivodeistvie legalizatsii dokhodov, poluchennykh prestupnym putem, i finansirovanii terrorizma. Rostov-na-Donu, 2014. S. 15-17. [el. resurs]: http://www.scienceforum.ru/2014/pdf/6685.pdf. Data obrashcheniya 12.04.2014.

11. Panenkov A.A. Problemy sovershenstvovaniya natsional'noi sistemy protivodeistviya legalizatsii dokhodov, poluchennykh prestupnym putem, i finansirovaniyu terrorizma i oruzhiya massovogo unichtozheniya // NB: Ekonomika, trendy i upravlenie. - 2014. - 1. - C. 13-30. DOI: 10.7256/23064595.2014.1.8110. URL: http://www.e-notabene.ru/etc/ article_8110.html

12. Len'shin D.I. Ugolovnye nakazaniya za prestupleniya ekstremistskoi napravlennosti: proble- my zakonodatel'nogo zakrepleniya i realizatsii // Administrativnoe i munitsipal'noe pravo. - 2011. - 4 . - C. 38-42.

13. Panenkov A.A. Problemy sovershenstvovaniya natsional'noi sistemy protivodeistviya legalizatsii dokhodov, poluchennykh prestupnym putem, i finansirovaniyu terrorizma i oruzhiya massovogo unichtozheniya // NB: Ekonomika, trendy i upravlenie. -2014. - № 1. - S.13-30. DOI: 10.7256/2306-4595.2014.1.8110. URL: http://e-notabene.ru/etc/article_8110.html

14. Lopatina V.V.. Problemy narkotrafika i legalizatsiya narkotikov v Latinskoi Amerike // Mezhdunarodnye otnosheniya. - 2014. - № 1. - S. 104-107. DOI: 10.7256/2305-560X.2014.1.10242

15. Ivanov A.G.. Legalizatsiya dragotsennykh metallov, poluchennykh prestupnym putem: problemy privlecheniya k ugolovnoi otvetstvennosti // Pravo i politika. - 2013. - № 2. - S. 104-107. DOI: 10.7256/18119018.2013.02.18

16. Panenkov A.A. Kriminologicheskie podkhody $\mathrm{k}$ resheniyu problem bor'by s terrorizmom i ego finansirovaniem i osobennosti prokurorskogo nadzora. Nekotorye predlozheniya po optimizatsii bor'by s terrorizmom i ego finansirovaniem na osnove nauchnykh issledovanii // NB: Natsional'naya bezopasnost'. - 2013. -№ 3. - S.17-135. DOI: 10.7256/2306-0417.2013.3.8754. URL: http://e-notabene.ru/nb/article_8754.html

17. Panenkov A.A. Kriminologicheskaya obuslovlennost' gosudarstvennoi politiki po bor'be s prestupnost'yu yavlyaetsya zalogom uspekha obespecheniya federal'noi bezopasnosti Rossii, a takzhe bor'by s terrorizmom i ego finansirovaniem// NB: Natsional'naya bezopasnost'. - 2012. - № 2. - S.188-236. DOI: 10.7256/2306-0417.2012.2.90. URL: http://e-notabene. $\mathrm{ru} / \mathrm{nb} /$ article_90.html

18. Muradyan S.V. Institutsional'nye osnovy bor'by s finansirovaniem terrorizma v Evropeiskom soyuze // NB: Rossiiskoe politseiskoe pravo. - 2013. - № 2. S.77-90. DOI: 10.7256/2306-4218.2013.2.800. URL: http://e-notabene.ru/pm/article_800.html

19. Panenkov A.A. Predvaritel'nyi analiz reagirovaniya pravookhranitel'nykh organov i spetssluzhb na prestupleniya terroristicheskoi napravlennosti v 2012 godu i prognoz na 2013 god v Rossii. Rezul'taty nauchnykh issledovanii 2010-2012 gg. po bor'be s istochnikami finansirovaniya terrorizma $v$ Respublike Ingushetiya (vyvody i predlozheniya) // NB: Natsional'naya bezopasnost'. - 2013. - № 1. - S.153-253. DOI: 10.7256/2306-0417.2013.1.326. URL: http://e-notabene. ru/nb/article_326.html 
DOI: $10.7256 / 1811-9018.2014 .6 .12061$

При цитировании этой статьи сноска на dоі обязательна

\section{Право и политика $6(174) \cdot 2014$}

20. Panenkov A.A. Kriminologicheskaya obuslovlennost' gosudarstvennoi politiki po bor'be s prestupnost'yuzalog uspekha $\mathrm{v}$ bor'be $\mathrm{s}$ terrorizmom $\mathrm{i}$ ego finansirovaniem v Rossii // NB: Natsional'naya bezopasnost'. - 2012. - № 1. - S.1-54. DOI: 10.7256/23060417.2012.1.109. URL: http://e-notabene.ru/nb/ article_109.html

21. Panenkov A.A. Bor'ba s terrorizmom i ego finansirovaniem ostanetsya aktual'noi i dolgovremennoi problemoi dlya Rossii // NB: Natsional'naya bezopasnost'. - 2013. - № 4. - S.19-77. DOI: 10.7256/23060417.2013.4.187. URL: http://e-notabene.ru/nb/ article_187.html

22. Malyshenko N.G.. Biznes-monitoring - sovremennyi instrument ekonomicheskoi bezopasnosti federal'nogo avtonomnogo vuza // Natsional'naya bezopasnost' / nota bene. - 2013. - № 5. - S. 104-107. DOI: 10.7256/2073-8560.2013.5.9556

23. A.A. Panenkov. Napravleniya sovershenstvovaniya bor'by s terrorizmom i ego finansirovaniem (po rezul'tatam provedennykh issledovanii) // Finansovoe pravo i upravlenie. - 2013. - № 1. - S. 104-107. DOI: 10.7256/.2013.1.4806

24. Astanin V.V. Protivodeistvie korruptsii: perspektivnye podkhody $\mathrm{k}$ preduprezhdeniyu i vozmeshcheniyu ushcherba // Administrativnoe i munitsipal'noe pravo. - 2013. - 7. - C. 719 - 722. DOI: 10.7256/19992807.2013.7.9084.

25. Antonova E.Yu. Ugolovnaya otvetstvennost' korporativnogo (kollektivnogo) sub"'ekta za korruptsionnye prestupleniya // NB: Voprosy prava i politiki. - 2013. - 3. - C. 192 - 220. DOI: 10.7256/23059699.2013.3.568. URL: http://www.e-notabene.ru/ 1r/article_568.html

26. Akopdzhanova M.O. Formirovanie sovremennogo zakonodatel'stva Rossiiskoi Federatsii ob ugolovnoi otvetstvennosti za prestupleniya protiv ustanovlennogo poryadka uplaty nalogov i sborov // Pravo i politika. - 2013. - 8. - C. 1022 - 1026. DOI: 10.7256/18119018.2013.8.8390. 